\title{
Syndactyly type 3
}

INSERM

\section{Source}

INSERM. (1999). Orphanet: an online rare disease and orphan drug data base. Syndactyly type 3. ORPHA:93404

Syndactyly type 3 (SD3) is a rare congenital distal limb malformation characterized by complete and bilateral syndactyly between the 4th and 5th fingers. 